\title{
Effect of Feed Supplementation by Moringa Oleifera Leaf Meal on Quail (Coturnix sp.) Growth Performances in the Sudano-Guinean Zone of Cameroon
}

Djitie Kouatcho François ${ }^{1 *}$, Djanabou Moussa ${ }^{1}$, Koné Mamadou ${ }^{2}$, Ndraouni Friki Lazare ${ }^{1}$, Bobga Aoudou ${ }^{1}$, Pidotcho Golomta $^{1}$, Ngoula Ferdinand ${ }^{3}$, Teguia Alexis ${ }^{3}$

${ }^{1}$ Laboratory of Applied Zoology, Department of Biological Sciences, Faculty of Sciences, University of Ngaoundéré, Cameroon

${ }^{2}$ Laboratory of Biology and Tropical Ecology, UFR Environment, University Jean Lorougnon Guédé, Daloa, Ivory Coast

${ }^{3}$ Laboratory of Animal Productions, Department of Animal Sciences, Faculty of Agronomy and Agricultural Sciences, University of Dschang, Cameroon

DOI: $10.36347 /$ sajb.2020.v08i02.004

| Received: 08.02.2020 | Accepted: 15.02.2020 | Published: 25.02.2020

*Corresponding author: Djitie Kouatcho François

Abstract

Original Research Article

This study was carried out to evaluate the effect of feed supplementation by Moringa oleifera leaf meal (MOLM) on quail growth performances. For this purpose, 192 quails of 21 days old were divided into 12 batches of 8 males and 8 females. $0,1,2$, or $3 \%$ of MOLM was added to the feed corresponding to treatments T0, T1, T2 and T3 respectively. Each of them was randomly assigned to 3 batches. Data were collected on growth parameters. At the $4^{\text {th }}$ weeks of the trial, 2 males, 2 females per batch were sacrificed to evaluate carcass and some internal organs characteristics. The main results showed that regardless of sex, the significantly higher $(224.13 \pm 30.69 \mathrm{~g})$ live weight was obtained with $2 \%$ of MOLM compared to the control $(203.83 \pm 16.67 \mathrm{~g})$. The significantly higher $(4.74 \pm 0.93)$ feed conversion ratio was obtained with the T3 treatment compared to T2 $(4.24 \pm 0.80 \mathrm{~g})$. Carcass yield of males ranged from 70 (T2) to $73 \%$ (T3) and from 67 (T2) to $69 \%$ (T0) in females. Only whole carcass yield, relative weights of the wishbones, neck and gizzard were significantly affected by MOLM. It has been concluded that MOLM can be used up to $3 \%$ to improve growth performance of quail.

Keywords: leaves, Moringa oleifera, growth, quail, sudano-guinean zone.

Copyright @ 2020: This is an open-access article distributed under the terms of the Creative Commons Attribution license which permits unrestricted use, distribution, and reproduction in any medium for non-commercial use (NonCommercial, or CC-BY-NC) provided the original author and source are credited

\section{INTRODUCTION}

Quail farming payed attention of Cameroonian farmers as a new way of diversifying sources of animal proteins, offering consumers new tastes and reinforcing the production of meat. Its low production cost associated with its small size, disease resistance, rapid growth and relatively short life cycle of up to 3 to 4 generations per year. Its high egg production from 250 to 350 / female / year [1, 2], as well as the supposed therapeutic virtues that characterize these eggs [3] are the factors that favored his expansion in recent years. However, although the production of this species seems to interest some breeders, its production performance remains relatively low. This is due to the fact that its production standards are not mastered in that environment. According to surveys conducted by Katchouang et al. [4], 60\% of breeders in the Mfoundi department in Central region of Cameroon have not received formal training for their breeding. In addition, the same study shows that $86 \%$ of Yaoundé farmers would use chicken feed while the remaining $14 \%$ will prepare their own feed without any training. However, there are many unconventional food resources in Sudano Guinean zone such as Moringa. oleifera, which could provide important nutrient, vitamin and micronutrient inputs to quail by adding it to commonly used ingredients. Studies by various authors $[5,6]$ have shown that $M$. oleifera leaves are rich in proteins, minerals, vitamins and amino acids such as arginine, lysine and methionine which are essential in poultry. According to several studies, the incorporation of $M$. oléifèra leaf meal into the diets of laying hens showed a significant improvement in productivity according to Kakengi et al. [7] and a significant increase in the weight of eggs according to Paguia et al. [8]. In Japanese quail, the best level of production performance in Algeria was obtained with $0.2 \%$ supplementation of the staple diet with $M$. oleifera leaves meal [9]. Since quail farming and nutritional need are not mastered in the Sudano-Guinean zone of Cameroon, the present study aimed to assess the effect of feed supplementation with $M$. oleifera leaves 
Djitie Kouatcho François et al., Sch Acad J Biosci, Feb, 2020; 8(2): 39-45

meal on growth performances and carcass characteristics in quail.

\section{MATERIAL AND METHODS \\ Presentation of the study area}

The study was conducted in Ngaoundéré in the Sudano Guinean zone of Cameroon. The area is located between the 6th and 8th degrees north latitude and between the 10th and 16th degree east longitude with an average altitude of $1000 \mathrm{~m}$. There is one rainy season of 8 months (April to November) and a dry season of 4 months (December to March). The rainfall is between 1500 and $1800 \mathrm{~mm} /$ year, the average annual humidity varies between $64.1 \%$ and $67.6 \%$ and the temperatures between 23 and $32^{\circ} \mathrm{C}$. Soils are generally fertile and appropriate for agro-pastoral activities. The vegetation consists mainly of shrub or tree savannas. Livestock is mainly cattle and small ruminants. Poultry farming is still very little developed [10].

\section{Materials and essay follow-up}

M. oleifera leaves were cut early in the morning and then dried in the shade before being transformed into powder and kept until use.

A total of 192 quails of 21 days old and average weight of $64.25 \pm 3.77 \mathrm{~g}$ were divided into 12 similar batches of 16 subjects ( 8 males and 8 females). They were housed in cages made of low-meshed planks and wire mesh at a density of 28 subjects $/ \mathrm{m}^{2}$. Four experimental diets (T0, T1, T2 and T3) formulated on the basis of the level $(0,1,2$ and $3 \%)$ of supplementation of the basic diet with $M$. oleifera leaves meal in the finishing phase. The percentage composition and the calculated chemical characteristics of the basic ration are recorded in Table 1.

Table-1: Feed percentage composition and calculated chemical characteristics

\begin{tabular}{|l|c|}
\hline Ingredients & Quantity (Kg) \\
\hline Maize & 63 \\
\hline Wheat bran & 4 \\
\hline Soybean meal & 14 \\
\hline Fishmeal & 5 \\
\hline Shellfish flour & 1 \\
\hline Bone meal & 1 \\
\hline CMAV 5\% flesh & 5 \\
\hline Palm oil & 2 \\
\hline Groundnut meal & 5 \\
\hline Total & $\mathbf{1 0 0}$ \\
\hline Calculated chemical characteristics: & \\
Crude Protein content (\%) 20,18; Metabolizable energy (kcal/Kg) 3013,78; Energy / & \\
Protein ratio149,34; Fat (\%) 5,45; Calcium (\%) 1,41; Phosphore (\%) 0,62; Lysine (\%) & \\
1,16 Methionine (\%) 0,44 &
\end{tabular}

The experimental diets were formulated by adding $0,1,2$ and $3 \%$ of the feed weight by $M$. oleifera leaves meal corresponding to treatments $\mathrm{T} 0, \mathrm{~T} 1, \mathrm{~T} 2$ and $\mathrm{T} 3$ respectively.

Each of the 4 experimental diets was randomly assigned to 3 batches in a completely randomized design with 4 treatments repeated 3 times each. Water and feed were distributed ad libitum throughout the 4 weeks of the trial. The animals benefited from similar management conditions.

\section{DATA COLLECTION Growth performance}

Experimental diets were weighed at the beginning of the week and distributed daily. Leftovers of each experimental unit were weighed every 7 days using an electronic scale of $5000 \mathrm{~g}$ range and $1 \mathrm{~g}$ accuracy. Weekly feed intake (FI) was calculated as the difference between the amount of feed distributed during the week and leftovers of the same week.
At the beginning of the test and every 7 days after, quails were weighed on an empty stomach in the morning using an electronic scale of $2000 \mathrm{~g}$ range and $0.1 \mathrm{~g}$ accuracy. The weekly weight gain was obtained by making the difference between two consecutive live weights.

Feed intake of each week was divided by weekly average weight gain (GMH) for the same period to obtain the Feed Conversion Ratio (FCR).

\section{Carcass characteristics}

At 07 weeks of age, 6 males and 6 females per treatment were slaughtered and characterized according to the method described by Genchev and Mihaylov [11] for the evaluation of the carcass. The carcass, liver, heart, gizzard, head, thigh, keel, wing and leg weight data allowed us to calculate carcass yield and relative weight of carcass parts or organs. 
Djitie Kouatcho François et al., Sch Acad J Biosci, Feb, 2020; 8(2): 39-45

\section{STATISTICAL ANALYSIS}

The data obtained were expressed as mean \pm standard deviation on the mean. One-way analysis of variance (ANOVA) was used according to the general linear model to compare the means of the different parameters. Duncan test was used at the $5 \%$ significance level to separate means in case of differences between treatments. IBM SPSS Statistics 21.0 software was used for analyzes.

\section{RESULTS}

\section{Average production performances}

The effect of MOLM supplementation on average production performance at 7 weeks (Table 2) shows that regardless of sex, feed intake (FI) was comparable between different treatments. Live weight significantly $(\mathrm{P}<0.05)$ varied from $203.83 \pm 16.67 \mathrm{~g}$ (T0) to $224.13 \pm 30.69 \mathrm{~g}$ (T2) and in females, from $213.96 \pm$ $18.62 \mathrm{~g}(\mathrm{~T} 0)$ at $251.66 \pm 6.79 \mathrm{~g}(\mathrm{~T} 2)$. In females and regardless of sex, the significantly highest values were recorded with $\mathrm{T} 2$ treatment compared with $\mathrm{T} 0$ treatment who were otherwise comparable to $\mathrm{T} 1$ and $\mathrm{T} 3$ treatments. In males, significantly higher live weight was recorded with control and $\mathrm{T} 2$ compared to $\mathrm{T} 3$ treatment. The observations made for the mean weekly weight gain were the same as those for live weight. Regardless of gender, the feed conversion ratio significantly $(\mathrm{P}<0.05)$ increased from $4.24 \pm 0.80 \mathrm{~g}$ (T2) to $4.74 \pm 0.93 \mathrm{~g}$ (T3), treatments supplemented with 1 and $3 \%$ MOLM and the control group were otherwise comparable $(\mathrm{P}>0.05)$. Supplementation of MOLM did not significantly affect feed conversion ratio of the different treatments in males. In females however, feed conversion ratio significantly $(\mathrm{P}<0.05)$ increased from $3.51 \pm 0.06 \mathrm{~g}(\mathrm{~T} 2)$ to $4.40 \pm 0.56 \mathrm{~g}$ (T0). The values of feed conversion ratio for T0, T1, and T3 treatments in one hand and for T1, T2 and $\mathrm{T} 3$ on the other hand remained similar.

Table-2: Quail production performances in finishing phase on the basis of experimental diets

\begin{tabular}{|c|c|c|c|c|c|}
\hline \multirow[t]{2}{*}{ Gender } & \multirow[b]{2}{*}{$\begin{array}{l}\text { Experimental } \\
\text { diets }\end{array}$} & \multicolumn{4}{|c|}{ production performances } \\
\hline & & $\begin{array}{c}\text { Total feed intake } \\
\text { (g) }\end{array}$ & Live weight (g) & $\begin{array}{l}\text { Live weight } \\
\text { gain }(\mathrm{g})\end{array}$ & $\begin{array}{c}\text { Total Feed } \\
\text { Conversion } \\
\text { Ratio }(g)\end{array}$ \\
\hline \multirow[t]{5}{*}{ Females } & T0 & & $213.96 \pm 18.62^{\mathrm{a}}$ & $37.42 \pm 9.31^{\mathrm{a}}$ & $4.40 \pm 0.56^{b}$ \\
\hline & T1 & & $227.37 \pm 11.73^{\mathrm{ab}}$ & $40.78 \pm 2.93^{\mathrm{ab}}$ & $3.98 \pm 0.25^{\mathrm{ab}}$ \\
\hline & $\mathrm{T} 2$ & & $251.66 \pm 6.79^{b}$ & $46.85 \pm 1.69^{b}$ & $3.51 \pm 0.06^{\mathrm{a}}$ \\
\hline & T3 & & $234.90 \pm 18.53^{\mathrm{ab}}$ & $42.66 \pm 4.63^{\mathrm{ab}}$ & $3.93 \pm 0.43^{\mathrm{ab}}$ \\
\hline & Mean & & $231.97 \pm 19.00$ & $41.93 \pm 4.75$ & $3.95 \pm 0.46$ \\
\hline \multirow[t]{5}{*}{ Males } & T0 & & $193.70 \pm 6.35^{\mathrm{b}}$ & $32.36 \pm 1.85^{\mathrm{b}}$ & $5.05 \pm 0.45^{\mathrm{a}}$ \\
\hline & $\mathrm{T} 1$ & & $187.40 \pm 4.27^{\mathrm{ab}}$ & $30.78 \pm 1.06^{\mathrm{ab}}$ & $5.27 \pm 0.30^{\mathrm{a}}$ \\
\hline & $\mathrm{T} 2$ & & $196.59 \pm 5.88^{b}$ & $33.06 \pm 1.47^{\mathrm{b}}$ & $4.98 \pm 0.12^{\mathrm{a}}$ \\
\hline & $\mathrm{T} 3$ & & $184.04 \pm 1.86^{\mathrm{a}}$ & $29.94 \pm 0.46^{\mathrm{a}}$ & $5.55 \pm 0.11^{\mathrm{a}}$ \\
\hline & Mean & & $190.43 \pm 6.67$ & $31.54 \pm 1.66$ & $5.21 \pm 0.33$ \\
\hline \multirow{5}{*}{ Mixed } & T0 & $653.12 \pm 26.73^{\mathrm{a}}$ & $203.83 \pm 16.67^{\mathrm{a}}$ & $34.89 \pm 4.16^{\mathrm{a}}$ & $4.73 \pm 0.58^{\mathrm{b}}$ \\
\hline & $\mathrm{T} 1$ & $648.45 \pm 13.44^{\mathrm{a}}$ & $207.38 \pm 23.27^{\mathrm{a}}$ & $35.78 \pm 5.81^{\mathrm{a}}$ & $4.62 \pm 0.74^{\mathrm{ab}}$ \\
\hline & $\mathrm{T} 2$ & $658.70 \pm 11.90^{\mathrm{a}}$ & $224.13 \pm 30.69^{\mathrm{b}}$ & $39.97 \pm 7.67^{b}$ & $4.24 \pm 0.80^{\mathrm{a}}$ \\
\hline & $\mathrm{T} 3$ & $665.79 \pm 20.52^{\mathrm{a}}$ & $209.47 \pm 30.24^{\mathrm{ab}}$ & $36.30 \pm 7.56^{\mathrm{ab}}$ & $4.74 \pm 0.93^{b}$ \\
\hline & Mean & $665.52 \pm 18.99$ & $211.20 \pm 25.38$ & $36.73 \pm 6.34$ & $4.58 \pm 0.75$ \\
\hline
\end{tabular}

\section{Live weight evolution and average weight gain}

The evolution of the average live weight of quails (Figure 1) as a function of the supplementation rate of $M$. oleifera leaves meal feed shows that at week 4, $\mathrm{T} 2$ treatment induced a live weight significantly higher $(109.15 \pm 17.81 \mathrm{~g})$ than $\mathrm{T} 3$ treatment $(101.4 \pm 13.55 \mathrm{~g})$. At week 5, the control treatment was similar to T2 and $\mathrm{T} 3$ treatments and also induced significantly $(\mathrm{P}<0.05)$ higher weights than the $\mathrm{T} 1$ treatment $(134.8 \pm 9.12 \mathrm{~g})$. By week 6 supplementation of feed by MOLM did not significantly $(\mathrm{P}>0.05)$ affect body weight. At the end of the study, feed supplemented at $2 \%$ with MOLM induced a significantly $(\mathrm{P}<0.05)$ higher live weight $(224.13 \pm 30.69 \mathrm{~g})$ compared to the control treatment $(203.83 \pm 16,67 \mathrm{~g})$.

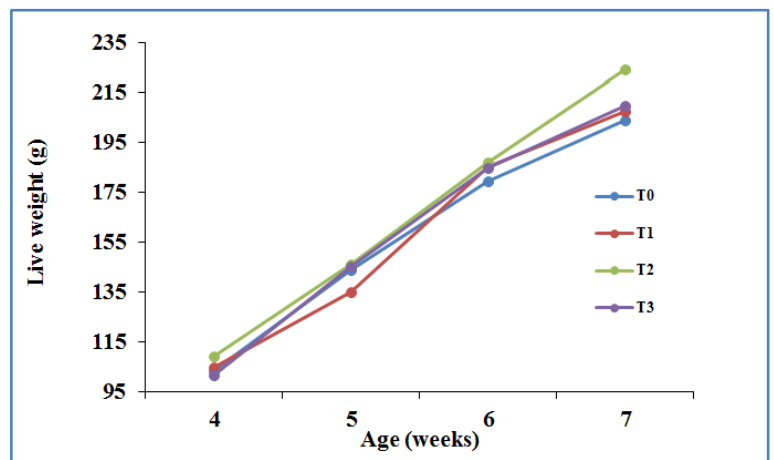

Fig-1 Evolution of the average live weigh regardless of sex and based on experimental diets 
Djitie Kouatcho François et al., Sch Acad J Biosci, Feb, 2020; 8(2): 39-45

\section{Feed conversion ratio}

Figure 2 shows the evolution of the Feed conversion ratio (FCR) as a function of the level of supplementation of $M$. oleifera leaves meal in feed. Control treatment induced significantly higher $(\mathrm{P}<0.05)$ feed conversion ratio at weeks $4(2.75 \pm 0.90 \mathrm{~g})$ and 6 $(5.39 \pm 0.59 \mathrm{~g})$ compared to the supplemented diets. At week 5, T1 induced the higher feed conversion ratio compared to other treatments which remained similar among them. At the end of the trial, the highest ( $P$ $<0.05)$ feed conversion ratio was obtained with $\mathrm{T} 1$ treatment $(13.97 \pm 8.03 \mathrm{~g})$ compared to $\mathrm{T} 2$ treatment $(7.85 \pm 4,07 \mathrm{~g})$ but remains comparable $(\mathrm{P}>0.05)$ to $\mathrm{T} 3$ and $\mathrm{T} 0$ treatments.

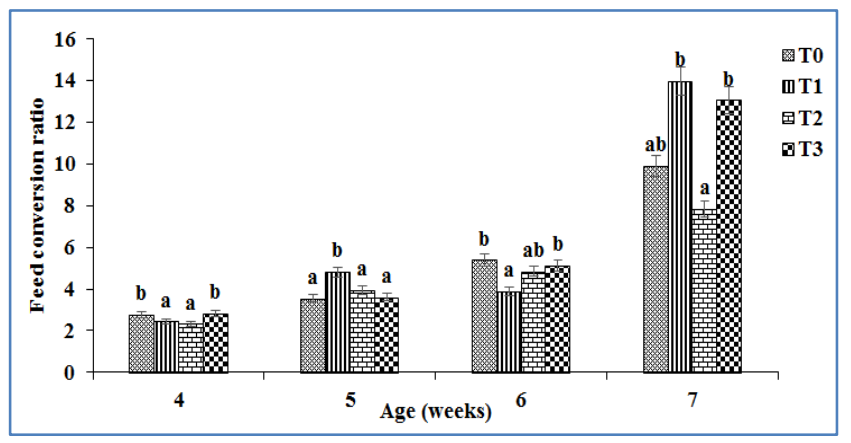

Fig-2: Weekly change in feed conversion ratio regardless of sex and based on experimental diets

\section{Carcass yield and proportions of different cuts parts}

On the summarizes of the effect of M. oleifera leaves meal supplementation on carcass yield of quail and the proportions (\% BW) of its different cuts parts at 7 weeks (Table 3), it appears that the standard carcass yield, the proportions of thighs, wings, heads, legs and back were not significantly $(\mathrm{P}>0.05)$ affected by the different levels of supplementation. The highest whole carcass yields $(\mathrm{P}<0.05)$ were obtained with diet supplemented at 1 and $2 \%(80.21 \pm 4.23 \mathrm{~g}$ and $80.04 \pm$ $3.58 \mathrm{~g}$ respectively) with MOLM. These values were also similar to that of the T3 treatment which was also similar to the control regardless of sex. The significantly ( $\mathrm{P}$ $<0.05$ ) highest chest proportions were recorded at $1 \%$ of supplementation compared to the control and T3 treatments. Chest proportions of $\mathrm{T} 2$ were otherwise similar $(\mathrm{P}>0.05)$ to those of all other treatments. T3 treatment showed significantly higher $(\mathrm{P}<0.05)$ neck proportions than other treatments. Those of comparable $\mathrm{T} 0$ and $\mathrm{T} 2$ treatments did not significantly differ between them but were higher than values recorded with $\mathrm{T} 1$ treatment.

Table-3: Carcass yield (\%) and relative weight of different parts in relation to body weight (\% BW \pm SD) at 7 weeks old according to the experimental diets

\begin{tabular}{|c|c|c|c|c|c|}
\hline \multirow{2}{*}{$\begin{array}{l}\text { Characteristics } \\
(\% \text { BW) }\end{array}$} & \multirow[t]{2}{*}{ Gender } & \multicolumn{4}{|c|}{ Experimental diets } \\
\hline & & T0 $(n=12)$ & $\mathrm{T1}(\mathrm{n}=12)$ & T2(n=12) & T3(n=12) \\
\hline \multirow{3}{*}{ Whole carcass yield } & Male & $77.44 \pm 0.58^{\mathrm{a}}$ & $83.37 \pm 1.89^{b}$ & $81.78 \pm 0.89^{b}$ & $80.32 \pm 4.20^{\mathrm{ab}}$ \\
\hline & Female & $74.90 \pm 0.94^{\mathrm{a}}$ & $77.0 \pm 3.36^{\mathrm{b}}$ & $78.32 \pm 4.72^{b}$ & $75.03 \pm 3.90^{\mathrm{ab}}$ \\
\hline & Mean & $76.17 \pm 1.56^{\mathrm{a}}$ & $80.21 \pm 4.23^{b}$ & $80.04 \pm 3.58^{b}$ & $77.68 \pm 4.63^{\mathrm{ab}}$ \\
\hline \multirow{3}{*}{$\begin{array}{l}\text { Standard carcass } \\
\text { yield }\end{array}$} & Male & $71.14 \pm 0.40^{\mathrm{a}}$ & $71.33 \pm 0.76^{\mathrm{a}}$ & $70.10 \pm 0.69^{\mathrm{a}}$ & $73.07 \pm 3.84^{\mathrm{a}}$ \\
\hline & Female & $69.18 \pm 1.72^{\mathrm{a}}$ & $68.07 \pm 0.64^{\mathrm{a}}$ & $66.80 \pm 2.84^{\mathrm{a}}$ & $68.10 \pm 4.35^{\mathrm{a}}$ \\
\hline & Mean & $70.17 \pm 1.56^{\mathrm{a}}$ & $69.70 \pm 1.89^{\mathrm{a}}$ & $68.44 \pm 2.59^{\mathrm{a}}$ & $70.56 \pm 4.59^{\mathrm{a}}$ \\
\hline \multirow[t]{3}{*}{ Chest } & Male & $23.45 \pm 0.89^{\mathrm{a}}$ & $28.41 \pm 0.87^{b}$ & $26.84 \pm 1.75^{\mathrm{ab}}$ & $25.41 \pm 1.39^{\mathrm{a}}$ \\
\hline & Female & $23.60 \pm 1.99^{\mathrm{a}}$ & $25.99 \pm 1.35^{b}$ & $24.12 \pm 1.05^{\mathrm{ab}}$ & $22.90 \pm 3.50^{\mathrm{a}}$ \\
\hline & Mean & $23.52 \pm 1.39^{\mathrm{a}}$ & $27.20 \pm 1.68^{b}$ & $25.49 \pm 1.97^{\mathrm{ab}}$ & $24.16 \pm 2.75^{\mathrm{a}}$ \\
\hline \multirow[t]{3}{*}{ Thigh } & Male & $16.00 \pm 0.47^{\mathrm{a}}$ & $15.24 \pm 1.30^{\mathrm{a}}$ & $15.31 \pm 1.08^{\mathrm{a}}$ & $15.54 \pm 1.02^{\mathrm{a}}$ \\
\hline & Female & $15.03 \pm 0.50^{\mathrm{a}}$ & $15.59 \pm 0.34^{\mathrm{a}}$ & $14.91 \pm 1.31^{\mathrm{a}}$ & $15.11 \pm 0.92^{\mathrm{a}}$ \\
\hline & Mean & $15.52 \pm 0.69^{\mathrm{a}}$ & $14.41 \pm 0.89^{\mathrm{a}}$ & $15.11 \pm 1.10^{\mathrm{a}}$ & $15.32 \pm 0.90^{\mathrm{a}}$ \\
\hline \multirow[t]{3}{*}{ Wings } & Male & $6.14 \pm 0.23^{\mathrm{a}}$ & $6.52 \pm 0.42^{\mathrm{a}}$ & $6.18 \pm 0.30^{\mathrm{a}}$ & $6.26 \pm 0.42^{\mathrm{a}}$ \\
\hline & Female & $7.02 \pm 1.12^{\mathrm{a}}$ & $5.51 \pm 0.42^{\mathrm{a}}$ & $6.22 \pm 0.75^{\mathrm{a}}$ & $5.97 \pm 0.35^{\mathrm{a}}$ \\
\hline & Mean & $6.58 \pm 0.87^{\mathrm{a}}$ & $6.21 \pm 0.60^{\mathrm{a}}$ & $6.20 \pm 0.51^{\mathrm{a}}$ & $6.11 \pm 0.38^{\mathrm{a}}$ \\
\hline \multirow{3}{*}{ Neck } & Male & $6.13 \pm 0.64^{b}$ & $3.74 \pm 0.40^{\mathrm{a}}$ & $5.22 \pm 0.40^{b}$ & $6.81 \pm 0.48^{\mathrm{c}}$ \\
\hline & Female & $5.82 \pm 1.19^{b}$ & $4.21 \pm 0.37^{\mathrm{a}}$ & $5.07 \pm 0.66^{b}$ & $7.66 \pm 0.86^{\mathrm{c}}$ \\
\hline & Mean & $5.97 \pm 0.98^{b}$ & $3.98 \pm 0.43^{\mathrm{a}}$ & $5.14 \pm 0.49^{b}$ & $7.23 \pm 0.30^{c}$ \\
\hline \multirow[t]{3}{*}{ Back } & Male & $18.82 \pm 0.40^{\mathrm{a}}$ & $16.88 \pm 0.51^{\mathrm{a}}$ & $16.28 \pm 1.88^{\mathrm{a}}$ & $17.25 \pm 1.88^{\mathrm{a}}$ \\
\hline & Female & $18.99 \pm 10.70^{\mathrm{a}}$ & $16.22 \pm 1.83^{\mathrm{a}}$ & $15.52 \pm 0.36^{\mathrm{a}}$ & $15.25 \pm 2.02^{\mathrm{a}}$ \\
\hline & Mean & $18.91 \pm 6.78^{\mathrm{a}}$ & $16.55 \pm 1.25^{\mathrm{a}}$ & $15.90 \pm 1.28^{\mathrm{a}}$ & $16.60 \pm 2.28^{\mathrm{a}}$ \\
\hline
\end{tabular}


Djitie Kouatcho François et al., Sch Acad J Biosci, Feb, 2020; 8(2): 39-45

\section{Proportions of organs in relation to the live weight of} quails

The effect of supplementing feed with $M$. oleifera leaves meal feed on relative weight on some quail's internal organs at 7 weeks of age as presented in Table 4 show that the different experimental diets did not induced any significant variation on heart, liver and abdominal fat proportions. The gizzard proportions of the control treatment were significantly the lowest compared to those of the T2 treatment and otherwise similar to other treatments. Despite the fact the the Gonado-Somatic Index (GSI) of males of treatment T1 was the significantly lowest and that the values obtained with control, T2 and T3 were similar, we however noticed an increase of the GSI between T0, T1 and T2 treatments. In females, GSI were not significantly affected $(\mathrm{P}>0.05)$ by the level of feed supplementation by $M$. oleifera leaves meal.

Table-4: Relative weight of some quail's organs and abdominal fat at 7 weeks of age according to experimental diets

\begin{tabular}{|c|c|c|c|c|c|}
\hline \multirow[t]{2}{*}{ Characteristics (\% BW) } & \multirow[t]{2}{*}{ Gender } & \multicolumn{4}{|c|}{ Experimental diets } \\
\hline & & T0 $(n=12)$ & T1(n=12) & T2(n=12) & T3(n=12) \\
\hline \multirow[t]{3}{*}{ Liver } & Male & $2,16 \pm 0,33^{\mathrm{a}}$ & $2,22 \pm 0,46^{\mathrm{a}}$ & $2,06 \pm 0,45^{\mathrm{a}}$ & $2,19 \pm 0,08^{\mathrm{a}}$ \\
\hline & Female & $2,81 \pm 0,51^{\mathrm{a}}$ & $3,24 \pm 1,00^{\mathrm{a}}$ & $2,96 \pm 1,04^{\mathrm{a}}$ & $3,07 \pm 0,78^{\mathrm{a}}$ \\
\hline & Mean & $2,48 \pm 0,52^{\mathrm{a}}$ & $2,73 \pm 0,89^{\mathrm{a}}$ & $2,51 \pm 0,86^{\mathrm{a}}$ & $2,63 \pm 0,51^{\mathrm{a}}$ \\
\hline \multirow[t]{3}{*}{ Heart } & Male & $0,59 \pm 0,54^{\mathrm{a}}$ & $0,92 \pm 0,05^{\mathrm{a}}$ & $0,84 \pm 0,27^{\mathrm{a}}$ & $0,81 \pm 0,17^{\mathrm{a}}$ \\
\hline & Female & $0,83 \pm 0,04^{\mathrm{a}}$ & $0,81 \pm 0,09^{\mathrm{a}}$ & $078 \pm 0,39^{\mathrm{a}}$ & $1,05 \pm 0,20^{\mathrm{a}}$ \\
\hline & Mean & $0,84 \pm 0,48^{\mathrm{a}}$ & $0,87 \pm 0,08^{\mathrm{a}}$ & $0,80 \pm 0,04^{\mathrm{a}}$ & $0,86 \pm 0,12^{\mathrm{a}}$ \\
\hline \multirow[t]{3}{*}{ Gizzard } & Male & $2,81 \pm 0,66^{\mathrm{a}}$ & $2,82 \pm 0,13^{\mathrm{ab}}$ & $3,83 \pm 1,09^{b}$ & $3,65 \pm 1,40^{\mathrm{ab}}$ \\
\hline & Female & $2,94 \pm 0,88^{\mathrm{a}}$ & $3,40 \pm 1,43^{\mathrm{ab}}$ & $4,59 \pm 0,23^{b}$ & $3,90 \pm 1,30^{\mathrm{ab}}$ \\
\hline & Mean & $2,87 \pm 0,70^{\mathrm{a}}$ & $3,11 \pm 0,96^{\mathrm{ab}}$ & $4,21 \pm 0,82^{b}$ & $3,77 \pm 1,21^{\text {ab }}$ \\
\hline \multirow[t]{3}{*}{ Abdominal fat } & Male & $0,67 \pm 0,40^{\mathrm{a}}$ & $0,46 \pm 0,10^{\mathrm{a}}$ & $1,04 \pm 0,48^{\mathrm{a}}$ & $0,65 \pm 0,35^{\mathrm{a}}$ \\
\hline & Female & $1,96 \pm 1,34^{\mathrm{a}}$ & $0,90 \pm 0,53^{\mathrm{a}}$ & $1,21 \pm 0,42^{\mathrm{a}}$ & $1,05 \pm 0,38^{\mathrm{a}}$ \\
\hline & Mean & $1,31 \pm 1,10^{\mathrm{a}}$ & $0,68 \pm 0,41^{\mathrm{a}}$ & $1,12 \pm 0,41^{\mathrm{a}}$ & $0,84 \pm 0,39^{\mathrm{a}}$ \\
\hline \multirow[t]{2}{*}{ Gonado somatic index } & Male & $1,84 \pm 0,34^{\mathrm{ab}}$ & $1,26 \pm 0,39^{\mathrm{a}}$ & $2,27 \pm 0,34^{b}$ & $2,50 \pm 0,36^{b}$ \\
\hline & Female & $1,04 \pm 0,71^{\mathrm{a}}$ & $1,10 \pm 0,85^{\mathrm{a}}$ & $2,18 \pm 1,51^{\mathrm{a}}$ & $0,40 \pm 0,27^{\mathrm{a}}$ \\
\hline
\end{tabular}

\section{DISCUSSION}

The relative higher weekly total FI were obtained with T3 treatment compared to the control. These results are close to those of Paguia et al. [8] who found that feed intake with levels of $0.20 \%, 0.40 \%$, $0.60 \%$ and $0.80 \%$ supplementation of the diet by MOLM in laying hens was significantly higher than the FI of the control batches. This increase in consumption could be explained by some palatability of MOLM in these birds because of its richness in vitamins and nutrients [12].

Overall, body weight has increased significantly with the supplementation level of MOLM in feed. at the end of the trial, T2 treatment induced high weights and the highest average weight gain regardless of the sex. These results are similar to those of Vali [13] who obtained at 63 days, a live weight of $221.92 \mathrm{~g}$ but are higher than those of Bonos [14], Abdel-Azeem and Abdel-Azeem [15] who recorded at 6 weeks, weights of $172 \mathrm{~g}$ and $199 \mathrm{~g}$ respectively. This variability of the weight could be explained either by the age or by the orientation of some lines towards precocity in the meat production $[16,17]$. The improvement in live weight and weight gain in our study with $\mathrm{T} 2$ treatment would mean a better assimilation of nutrients due to a level of supplementation of $M$. oleifera leaves meal which seems to be optimal for the finishing period [7].
FCR increased overall over time. The high values of weekly FCR recorded during the last few weeks of growth, especially could be justified by the high feed consumption coupled with the low weight gains for the same period the highlighting the decrease in the bird's ability to convert the food at the end of growth periods $[18,19]$.

Treatments $\mathrm{T} 1$ and $\mathrm{T} 2$ presented the highest whole carcass proportion compared to the control and could be due to an optimal level of MOLM in the diet. David et al. [20] found that MOLM improves carcass yields at slaughter compared to the control in broilers, which is also the case in our trial for the whole carcass and not for the standard. This increase in whole carcass yield could be due to the fact that $M$. oleifera leaves meal is concentrated in nutrients in the raw form that also appears to reduce the activity of pathogenic bacteria and improves the digestibility of food, thus helping poultry to express its genetic potentials [21]. Indeed, replacement of antibiotic growth promoters with MOLM by $0.1 \%$ has been beneficial on carcass growth and carcass yield of broilers David et al. [20].

Regardless of gender, the significantly higher chest proportions were induced with $\mathrm{T} 2$ treatment. This result is contrary to the observations of Corrêa et al. [22] who reported that the proportion of the chest increased significantly with the level of protein in the ration in 
Djitie Kouatcho François et al., Sch Acad J Biosci, Feb, 2020; 8(2): 39-45

female quail. Our results, however, corroborate those of Seyed-Alireza et al. [23] who found by feeding Japanese quail with diet whose energy-protein ratio ranged from 107 to 138 , significant effects on the proportions of the chest. The low proportions of female chest compared to males in this study are consistent with the results of Bonos et al. [14] who fed quail with a diet containing growth promoters, had the same trends as ours.

As with heart and abdominal fat, the proportions of the different batches were comparable to the control group, with slight increases with the supplementation level of MOLM. similar trends were obtained by Bonos et al. [14] and Shayan et al. [24], although lower levels (1.66 to $1.99 \%$ ), were recorded in Western highland of Cameroon by Djitie et al. [25] and could then be explained either by the treatments and/or the environmental conditions amongst others. The T2 treatment induced the relative weight of the gizzards significantly higher compared to the control group, which is contrary to the relative weight of gizzard of Coturnix japonica at 07 weeks of age according to Attia et al. [26]. This result could be explained by the hyperactivity of the gizzard which is the crusher muscle of the digestive tract then lead to his development. However, Ologhobo et al. [27] observed in their study that the relative weight of the gizzard decreased significantly by increasing the supplementation levels of the $M$. oleifera leaves meal feed compared with control lots, which is not the trend obtained in our work. In addition, a difference between the ratio of gizzard/live weight was observed in favor of females in the control group compared with males. It may be related to increase feed consumption by females in preparation for oviposition [2]. The significantly higher gonado somatic index recorded in male with $\mathrm{T} 2$ and $\mathrm{T} 3$ could be lead to a good development of testis and precocity in the sexual maturity.

\section{CONCLUSION}

At the end of this study, diets supplemented with Moringa oleifera leaves meal increased growth parameters and carcass characteristics in general. $2 \%$ supplementation Moringa oleifera leaves meal significantly improved live weight, average weekly weight gain, feed conversion ratio, whole carcass yield, chest, neck and gizzard relative weight compared to the diet without supplementation. It has then been concluded that MOLM can be used up to $3 \%$ to improve growth performance at finishing phase but a diet supplementation with $2 \%$ Moringa oleifera is the most appropriate the most appropriate to improve growth performance at finishing phase.

\section{REFERENCES}

1. Biagini F. Petits et mini-élevages dans le monde: principales espèces d'intérêt. Synthèse bibliographique. Biologie géosciences agro ressources et environnement productions animales en régions chaudes synthèse. Ecole Nationale Supérieure Agronomique de Montpellier Place Viala, 34060 Montpellier Cedex Master. 2006; 31.

2. Sauveur R. Reproduction des volailles et production d'œufs. INRA Paris France. 1988; 450.

3. Tunsaringkarn T, Tungjaroenchai W, and Siriwong W. Nutrient Benefits of Quail (Coturnix Coturnix Japonica) Eggs. International Journal of Scientific and Research Publications. 2013 3(5): 1-8

4. Katchouang ASN, Djitie FK, Meutchieye F, Kana JR et Teguia A. Caractéristiques des élevages de caille (Coturnix sp.) dans le département du Mfoundi, région du Centre, Cameroun. Livestock Research for Rural Development. 2015; (27), Article\#77.

http://www.lrrd.org/lrrd27/4/katc27077.html

5. Tendonkeng F, Boukila B, Beguide A, et Pamo TE. Essai de substitution du tourteau de soja par la farine de feuilles de Moringa oleifera dans la ration finition des poulets de chair. Revue Africaine de Santé et de Productions Animales. 2009; 7(5).

6. Olugbemi TS, Mutayoba SK, Lekule FP. Effect of Moringa (Moringa oleifera) inclusion in cassava based diets fed to broiler chickens. International Journal of Poultry Science. 2010;9(4):363-7.

7. Kakengi AMV, Kaijage JT, Sarwatt SV, Mutayoba SK, Shem MN, Fujihara T. Effect of Moringa oleifera leaf meal as a substitute for sunflower seed meal on performance of laying hens in Tanzania. Livestock Research for Rural Development. 2007; 9 (4). 446.

8. Paguia HM, Paguia R Q, Balba CH, ET Flores RC. Utilization and evaluation of Moringa oleifera L. As poultry feeds. Apcbee Procedia. 2014; (8): $343-$ 347.

9. Elkloub MEL, Moustafa, Riry FH, Shata, Mousa MAM, Hanan A H Alghonimy and Youssef SF. Using moringa oleifera leaf meal on performance of Japanese quail. Egyptian poultry of Science. 2015; (35). 14

10. Mbogning E, Tchoumboue J, Damasse F, Sobze MS et Canini A. Caractéristiques physico-chimiques des miels de la zone Soudano-guinéenne de L'Ouest et de l'Adamaoua.Tropicultura. 2011; (3): 168-175.

11. Genchev A, Mihaylova G, Ribarski S, Pavlov A, Kabakchiev M. Meat quality and composition in Japanese quails. Trakia Journal of Science. 2008; (6): 72-82.

12. Broin M. Composition nutritionnelle des feuilles de Moringa oleifera. CTA. 2005; 5.

13. Vali N. Growth, feed consumption and carcass composition of Coturnix japonica, Coturnix ypsilophorus and their reciprocal crosses. Asian Journal of Poultry Science. 2009; 3(4): 132-137.

14. Bonos EM, Christaki EV ET Florou-Paneri PC. Performance and carcass characteristics of Japanese quail as affected by sex or mannan oligosaccharides and calcium propionate. South African Journal of Animal Science. 2010; 40 (3): 173-181. 
Djitie Kouatcho François et al., Sch Acad J Biosci, Feb, 2020; 8(2): 39-45

15. Abdel-Azeem et Abdel-Azeem F. The influence of different stocking density and sex on productive performance and some physiological traits of Japanese quail. Egyptian Poultry Science Journal. 2010; (30), 203-227.

16. Campbell JR, Kenealy MD, Campbell KL. Animal Sciences: the biology, care and production of domestic animals. 4th Edition, McGraw Hill, Boston, San Francisco, 2003. 509 p.

17. Alkan S, Karabăg K, Galiç A, Karsli $\mathrm{T}$ and Balcioğlu MS. Determination of Body Weight and Some Carcass Traits in Japanese Quails of Different Lines KafkasUniv Vet FakDerg. 2010b; 16 (2): 277-280.

18. INRA. L'alimentation des animaux monogastriques: Porcs, lapins, volailles. 1989; 2ème Edition. INRA, Paris 282p.

19. Berrama Z, Mefti H, Kaidi R et Souames S. Caractérisation zootechnique et paramètres génétiques des performances de croissance de la caille japonaise Coturnix japonica élevée en Algérie. Livestock Research for Rural Development. 2011; (23), Article \#3.

20. David, LS, Vidanarachchi JK, Samarasinghe K, Cyril HW et Dematawewa CMB. Effects of Moringa based Feed Additives on the Growth Performance and Carcass Quality of Broiler Chicken. Tropical Agricultural Research. 2012; 24 (1): 12-20.

21. Gaia V, Fry NK, Afshar B, Lück PC, Meugnier H, Etienne J, Peduzzi R, Harrison TG. Consensus sequence-based scheme for epidemiological typing of clinical and environmental isolates of Legionella pneumophila. Journal of clinical microbiology. 2005 May 1;43(5):2047-52.
22. Correa, F., Jakubský, V., \& Plyushchay, M. S. (2008). Finite-gap systems, tri-supersymmetry and self-isospectrality. Journal of Physics A: Mathematical and Theoretical, 41(48), 485303.

23. Seyed-Alireza S, Mehrdad I, Khosro G, Afshar M, Vahid R, Hasan F, Kamel A, Samad Zamanzad G. Effect of varying dietary energy to protein ratio on productive performance and carcass characteristics of Japanese quail. Animal's biological research. 2011; 2 (1):149-155.

24. Shayan B S, Eila N et Norozian H. The effect of decreased crude protein diets on performance, immune response and carcass traits of Japanese quail chickens. Annals of Biological Research. 2013; 4 (2) :313-317

25. Kouatcho FD, Kana JR, Ngoula F, Nana NF, Teguia A. Effet du niveau de protéines brutes sur la croissance et la carcasse chez la caille (Coturnix sp) en phase de finition dans les Hautes Terres du Cameroun. Livestock Research for Rural Developmen. 2015;27(8).

26. Attia YA, Abd El-Hamid AE, Ellakany HF, Bovera F, Al-Harthi MA et Ghazaly SA. Growing and laying performance of Japanese quail fed diet supplemented with different concentrations of acetic acid. Italian Journal of Animal Science. 2013; 12 (e37): 222-229.

27. Ologhobo, A D, Akangbe, EI, Adejumo, IO and Adeleye, O. Effect of Moringa oleifera leaf meal as replacement for oxytetracycline on carcass characteristics of the diets of broiler chickens. Annual Research and Review in Biology. 2014; 4(2): 423-431. 